\title{
One hundred years of history and thirty together
}

\section{Cien años de historia y treinta en conjunto}

\author{
Manuel Garza-León ${ }^{1 *}$, Everardo Hernández-Quintela², Gerardo García-Aguirre ${ }^{3}$, \\ Roberto González-Salinas ${ }^{3}$ and Óscar Guerrero-Berger ${ }^{3}$
}

${ }^{1}$ Current Editor-in-chief; ${ }^{2}$ Editor-in-chief 2009-2012; ${ }^{3}$ Current co-editor. Revista Mexicana de Oftalmología, Sociedad Mexicana de Oftalmología, Mexico City, Mexico

The secret of my success was to surround myself with people smarter than me. Andrew Carnegie

The Asociación para Evitar la Ceguera en México (APEC) celebrates its first 100 years of history this year. To celebrate this important achievement, in this volume of the journal, doctors Sánchez Huerta, Sánchez Fontán and Salcedo Casillas publish a brief review of the main events that have led to one of the most important ophthalmology hospitals in our country. This history article covers from the conception of the association by doctors José de Jesús González and José Terrés to its foundation on August 13, 1918. It describes the different assistance duties, the mission committed to help the unprotected, with a high degree of humanist sense, the dialectical process of the scientific and technological contribution to society, and the various physical spaces where it has existed. Finally, they recount what APEC is today and the future vision that guides them.

Undoubtedly, the history of APEC is closely related to the history of the Revista Mexicana de Oftalmología (RMO). As we mentioned in the editorial of the previous volume $^{1}$, the RMO arises from the union of the Anales de Oftalmología (ISSN 0187-4519 Ann de Oftalmol) with the Archivos de la Asociación para Evitar la Ceguera en Mexico (ISSN 0004-489X Arch Asoc Evit Ceguera Mex,), the only Mexican ophthalmology journal indexed in Pubmed from 1942 to 1986, the year of the merger of both journals ${ }^{2}$, which makes it one of the oldest ophthalmology journals in Latin America that maintained its quarterly publication during that period.

In addition to this important contribution, the relationship between the RMO and APEC has been enriched with the innumerable articles that have been prepared and published by members of the Dr. Luis Sánchez Bulnes Hospital, as well as by some of the multiple graduates of their educational programs and, finally, as readers and reviewers that have made us grow as a journal.

For all this, from the RMO we join the celebration of these first 100 years and we hope to continue building this major relationship for another hundred more.

\section{References}

1. Hernandez-Quintela E, Navas-Perez A, Garza-Leon M. Los primeros 120 años de la Revista Mexicana de Oftalmología. Rev Mex Oftalmol. 2018; 92(5):225-6.

2. Catálogo electrónico del National Library of Medicine. Disponible en: https://www.ncbi.nlm.nih.gov/nlmcatalog?term=\%22Arch+Asoc+Evit+Ceguera+Mex\%22[Title+Abbreviation] 